\title{
Stomach Content Analysis of a Dugong (Dugong dugon) from South Sulawesi, Indonesia
}

\author{
Paul L. A. Erftemeijer ${ }^{\mathrm{A}}$, Djunarlin $^{\mathrm{B}}$ and Willem Moka ${ }^{\mathrm{B}}$ \\ A Netherlands Institute of Ecology, Centre for Estuarine and Coastal Ecology, Vierstraat 28, \\ 4401 EA Yerseke, The Netherlands, and Catholic University of Nijmegen, The Netherlands. \\ ${ }^{8}$ Laboratory for Marine Biology, Hasanuddin University (UNHAS), Tamalanrea, \\ Ujung Pandang, Indonesia.
}

Eublication no. 635 Netherlands Institute of Ecology

Centre for Estuarine and Coastal Ecology, Yerseke, The Netherlands.

Abstract

A quantitative analysis of the stomach contents of an individual fermale dugong (Dugong dugon) caught by fishermen in February 1991 in the coastal waters of South Sulawesi, Indonesia, is presented. Of the total dry weight of digesta (about $3.4 \mathrm{~kg}$ ), $98.9 \%$ consisted of seagrass material. Rhizome and root material of smaller pioneering genera (i.e. Halophila, Halodule, Cymodocea) accounted for $71 \cdot 5 \%$ of the total dry weight. Enhalus acoroides dominated among leaf material (about 50\%), but its contribution to the total biomass of the stomach contents was only 13.5\%. Rhizome material of Enhalus and Thalassia was absent. The amount of sediment in the stomach was negligible. The results are compared with those from similar studies, and the implications for possible feeding selectivity are discussed.

\section{Introduction}

The dugong, Dugong dugon (Müller), is a truly marine, herbivorous mammal, known to feed predominantly on seagrasses. Although observations derived from the stomach contents of a single dugong might not be sufficient to draw conclusions about the feeding ecology of the species, the increasing amount of recent literature on the stomach contents of dugongs from other areas enables a comparison to be made. The IUCN Mammal Red Data Book (Heinsohn 1982) gives the status of the dugong as 'vulnerable', which justifies the publication of any available information on the species. It is unlikely that large numbers of dugongs will become available for analysis in Indonesia, where dugong populations are considered to be under pressure and the species has been given a protected status. The present paper reports the analysis of the stomach contents of a dugong from South Sulawesi, Indonesia.

\section{Materials and Methods}

An adult female dugong was accidently caught in the nets of a local fisherman on 22 February 1991 at Bone Lola, a shallow submerged reef north of Barang Lompo island in the Spermonde Archipelago, South Sulawesi (Fig. 1). The animal was sold to a fishing family at the island and slaughtered for its meat (reportedly about $70 \mathrm{~kg}$ ). The authors were able to purchase the stomach for analysis of its contents. The full stomach measured roughly $30 \times 50 \mathrm{~cm}$ and had a total weight of about $23 \mathrm{~kg}$. Approximately $20 \mathrm{~kg}$ (wet weight) of macerated plant material was present in the stomach. A sample of the stomach contents was dried at $80^{\circ} \mathrm{C}$ to constant dry weight; this sample contained $83 \%$ water, indicating a total dry weight of $3.4 \mathrm{~kg}$ of plant material in the stomach. Three samples of digesta (about $5 \mathrm{~g}$ wet weight each) were randomly taken from the cardiac region of the main sac of the stomach and preserved in $4 \%$ formaldehyde in sea water. 


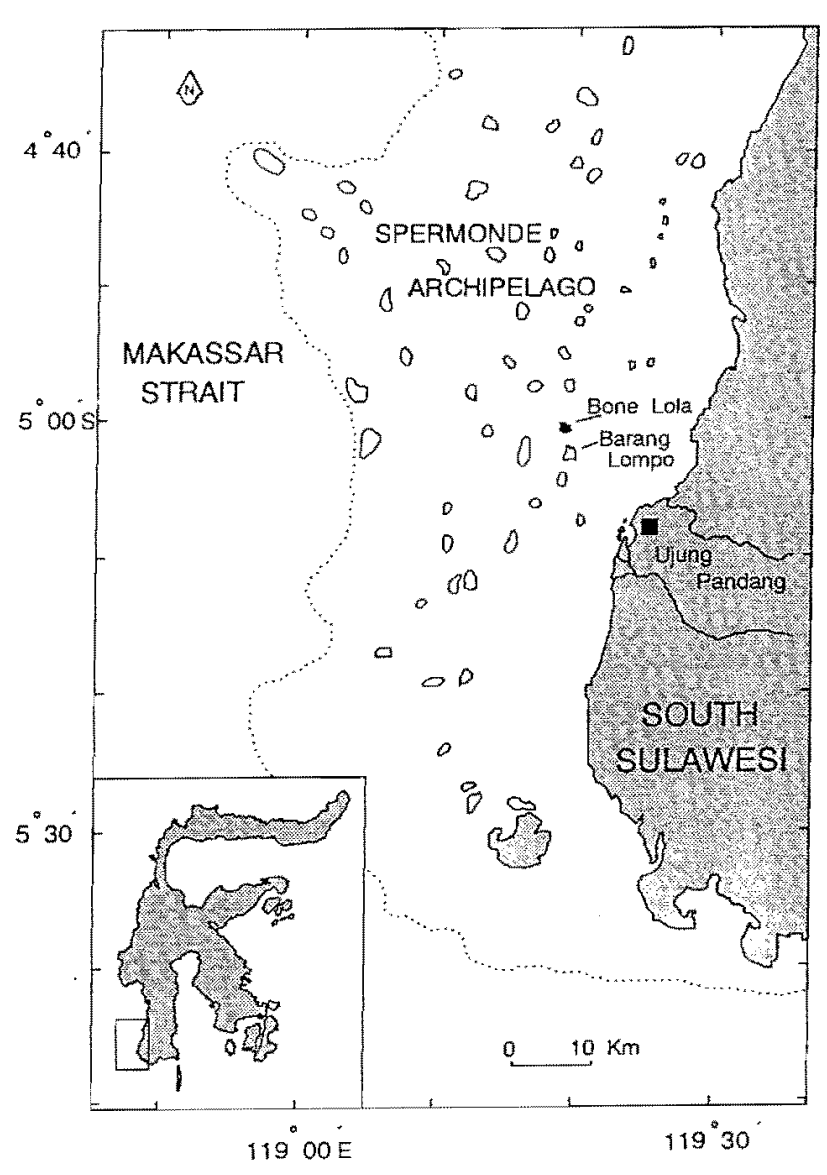

Fig. 1. Study area, showing the localities mentioned in the text.

Fragments of plant tissue from the three preserved samples were analysed microscopically and compared with a reference collection of seagrass leaf tissues. In all, 11 seagrass species of seven genera occur in the Spermonde Archipelago and adjacent coastal areas of South Sulawesi (Erftemeijer, unpublished data). The reference collection covered representative species of all seven genera that were collected in the study area. Epidermal-cell morphology, which shows characteristic differences in size and shape for all of the seagrass genera present in the study area, was used for reliable identifications according to the methods of Channells and Morrissey (1981).

In all, 2933 fragments of plant tissue (divided over the three samples) were identified and categorized according to genus for the leaf material; rhizome + root material and algal tissue (both of which were not identified to genus) were recorded as separate categories. After the total numbers of fragments in each category were counted, the sorted tissues from each sample were dried separately for $48 \mathrm{~h}$ at $80^{\circ} \mathrm{C}$ to determine the dry weights.

\section{Results}

The stomach contents of the female dugong in this study consisted almost entirely of seagrass tissue, which accounted for about $99 \%$ of the total dry weight (Table 1). Algae represented only $0.5 \%$ (dry weight) of the stomach contents, although epiphytic microalgae may have been overlooked. Indeed, the dugong is reported to feed almost exclusively on seagrasses throughout its range (Lanyon et al. 1989), eating significant amounts of algae only when seagrasses are scarce (Spain and Heinsohn 1973; Heinsohn and Spain 1974). The genus Enhalus (represented only by a single species, Enhalus acoroides) occurred most frequently 
and accounted for more than $50 \%$ of all leaf fragments in the samples and for $13.5 \%$ of the total dry weight. Leaf material of the genus Halophila (of which three species occur in the area) was also remarkably frequent in the samples but accounted for only $6.7 \%$ of the total dry weight. Other genera encountered included Thalassia, Halodule, Cymodocea and Syringodium, but none of these occurred in considerable proportions. Of the total number of tissue fragments investigated, $31 \%$ was rhizome and root material, which accounted for $71.5 \%$ of the total dry weight. Although rhizome material was not identified to genus, it was noticed that rhizomes from Enhalus acoroides and Thalassia hemprichii were absent. These two species have rhizomes and roots that penetrate deeply into sediments and so are not easily removed and eaten. In addition, the rhizomes of these two species have distinct cuticles and thickened and lignified cell walls. The absence of rhizomes of Enhalus and Thalassia from the stomachs of dugongs has been reported earlier (Anderson 1981; Marsh et al. 1982; Lanyon et al. 1989). No parasitic nematodes or other parasites were found in the cardial sac of the stomach. The amount of sediment in the stomach was negligible. Heinsohn and Birch (1972) also reported very little sand in dugong digesta.

\begin{tabular}{|c|c|c|}
\hline & $\begin{array}{c}\text { Relative } \\
\text { frequency }(\%) \\
\bar{X} \pm \mathrm{s} . \mathrm{d} .\end{array}$ & $\begin{array}{c}\text { Dry-weight } \\
\text { composition }(\%) \\
\bar{X} \pm \text { s.d. }\end{array}$ \\
\hline Enhahus & $35 \cdot 7 \pm 6 \cdot 3$ & $13 \cdot 5 \pm 1 \cdot 1$ \\
\hline Halophila & $15 \cdot 2 \pm 5 \cdot 4$ & $6 \cdot 7 \pm 1 \cdot 4$ \\
\hline Halodule & $6 \cdot 0 \pm 1 \cdot 6$ & $1 \cdot 0 \pm 0 \cdot 4$ \\
\hline Thalassia & $5 \cdot 4 \pm 1 \cdot 4$ & $2 \cdot 1 \pm 0 \cdot 4$ \\
\hline Cymodocea & $4 \cdot 7 \pm 1 \cdot 4$ & $2 \cdot 6 \pm 0 \cdot 4$ \\
\hline Syringodium & $0 \cdot 3 \pm 0 \cdot 2$ & $1 \cdot 5 \pm 0 \cdot 9$ \\
\hline Macroalgae & $0.7 \pm 0.5$ & $0.5 \pm 0.4$ \\
\hline Unidentified & $0 \cdot 9 \pm 1 \cdot 1$ & $0.5 \pm 0.4$ \\
\hline Rhizome and toot material & $31 \cdot 1+8 \cdot 0$ & $71 \cdot 5 \pm 1 \cdot 0$ \\
\hline
\end{tabular}

\section{Discussion}

The dominance of Enhalus acoroides among the leaf fragments in the stomach contents of the female dugong in this study contrasts with several reports for other areas (Gohar 1957; Lipkin 1975; Wake 1975; Anderson and Birtles 1978) where smaller, pioneering species, notably Halodule uninervis, dominated in dugong stomachs. Recent studies in Ambon (Indonesia) also indicate a strong preference by the dugong population in that area for sparse stands of Halodule uninervis (de Iongh 1990; Brasseur and de Jong 1991). Dugong feeding tracks were found almost exclusively in intertidal Halodule stands, although five other species, including Enhalus acoroides, occurred in dense beds nearby. Halodule occurred in $95 \%$ of 96 stomachs from Queensland dugongs, accounting for $44 \%$ of the non-rhizomatous portion in the stomachs (Marsh et al. 1982). The study by Marsh et al. (1982) showed variability among individual dugongs in the dominant species of seagrass eaten, which might put in doubt conclusions drawn from a single animal. Several authors have supported the view that dugongs feed according to food availability within selected feeding areas (Wake 1975; Heinsohn 1981; Marsh et al. 1982). During aerial surveys in 
Australia, the highest densities of dugongs were seen in coastal seagrass beds (Lanyon et al. 1989). Heinsohn et al. (1977) also reported a preference by dugongs for foraging in shallow coastal waters. Several shallow areas along the western coast of the southern part of South Sulawesi are characterized by monospecific seagrass beds of Enhalus acoroides bordered by mangroves (which have largely been converted into fish ponds). Conversely, mixed seagrass beds with up to four or five species occur on the shallow reef flats of the coral islands off the coast. Judging from the relative frequencies of leaf material from the different seagrass species in the stomach of the dugong in the present study, one might conclude that this dugong had been foraging primarily in coastal (Enhalus) seagrass beds.

However, when the total stomach contents are taken into consideration (i.e. including the rhizomatous portion), smaller pioneering genera clearly dominate. Rhizome and root material of smaller species accounted for over $70 \%$ of the total dry weight. This indicates that the dugong had been foraging primarily on smaller pioneering seagrass species rather than on Enhalus.

No feeding tracks of dugongs were observed in the study area, although some reports (Allen et al. 1976) and interviews with local fishermen suggest that dugongs are still frequenting the area, albeit in low numbers. However, if grazing pressure is low (as is implied by the low numbers of animals reported from this area), feeding trails may not be abundant, even when the seagrass beds consist of mixed species. Besides, as suggested by Brasseur and de Jong (1991), feeding tracks are probably absent in localities where tallgrowing seagrass species predominate (i.e. Amphibolis antarctica, Enhalus acoroides, Thalassia hemprichii) since the grazing of dugongs on these species is limited to the leaves. Feeding tracks are formed only when the dugongs dig up the whole plant, including the rhizomes. In this respect, Anderson (1991) recently suggested that the common name of the dugong should be changed to 'sea pig', with 'river cow' being a more appropriate name for the closely related manatee, which does not show such digging behaviour.

\section{Acknowledgments}

Inayah Yasir provided valuable assistance in the microscopic analysis of seagrass tissue. Pak Ance Lanti from Barang Lompo is acknowledged for kindly providing us with information on the animal and for offering us the stomach. Professor Dr P. H. Nienhuis, Ir $\mathbf{H}$. de Iongh and Sara Mathews provided helpful comments on earlier drafts of this paper. The present observations were made while P.L.A.E. was working on a Ph.D. study of nutrient dynamics in tropical seagrass beds, funded by the Netherlands Foundation for the Advancement of Tropical Research (WOTRO, Grant No. W84-293). The Indonesian Institute of Sciences (LIPI) is acknowledged for granting permission to carry out this study. This is Communication No. 635 of the Netherlands Institute of Ecology, Centre for Estuarine and Coastal Ecology, The Netherlands.

\section{References}

Allen, J, F, Lepes, M. M., Budiarso, I. T., Sumitro, and Hammond, D. (1976). Some observations on the biology of the dugong (Dugong dugon) from the waters of South Sulawesi. Aquatic Mammalogy 4(2), 33-48.

Anderson, P. K. (1981). The behaviour of the dugong (Dugong dugon) in relation to conservation and management. Bulletin of Marine Science 3, 640-77.

Anderson, P. K. (1991). River cows and sea pigs? A proposal for revision of sirenian popular names. Sirenews No. 16, 3-4. (IUCN/SSC Sirenia Specialist Group: Washington.)

Anderson, P. K, and Birtles, A. (1978). Behaviour and ecology of the dugong, Dugong dugon (Sirenia): observations in Shoalwater and Cleveland Bays, Queensland. Australian Wildife Research $5,1-23$.

Brasseur, S., and de Jong, G. (1991). Survey of the dugong in the Moluccas and the recolonization of their feeding tracks. AID-Environment (Amsterdam) Project Report. 65 pp. 
Channells, P. W, and Morrissey, J. (1981). Technique for analysis of seagrass genera present in dugong stomachs, including a key to north Queensland seagrasses based on cell details. In "The Dugong: Proceedings of a Seminar/Workshop Held at James Cook University of North Queensland, Australia, 8-13 May 1979'. (Ed. H. Marsh.) pp. 303-9. (James Cook University of North Queensland: Townsville.)

Gohar, H. A. F. (1957). The Red Sea dugong. Publications, Marine Biological Station, al Ghardaqa 9, 3-49.

Heinsohn, G. E. (1981). The dugong in the seagrass ecosystem. In "The Dugong Proceedings of a Seminar/Workshop Held at James Cook University of North Queensland, Australia, 8-13 May 1979'. (Ed. H. Marsh.) pp. 162-3. (James Cook University of North Queensland: Townsville.)

Heinsohn, G. E. (1982). Dugong Dugong dugon (Müller, 1776). Order Sirenia, Family Dugongidae. In "IUCN Mammal Red Data Book". (Eds J. Thornback and M. Jenkins.) Part I, pp. 417-27. (International Union for Conservation of Nature and Natural Resources: Gland, Switzerland.)

Heinsohn, G. E., and Birch, W. R. (1972). Foods and feeding habits of the dugong, Dugong dugon (Erxleben), in northern Queensland, Australia. Mammalia 36, 414-22.

Heinsohn, G. E., and Spain, A. V. (1974). Effects of a tropical cyclone on littoral and sub-littoral biotic communities and on a population of dugongs (Dugong dugon (Müller)). Biological Conservation $6,143-52$.

Heinsohn, G. E., Wake, J., Marsh, H., and Spain, A. V. (1977). The dugong (Dugong dugon (Müller)) in the seagrass system. Aquaculture 12, 235-48.

de longh, H. (1990). Monitoring, management and conservation of populations of dugong and their habitat in Maluku Province, Indonesia. AID-Environment (Amsterdam) Second Interim Report. $44 \mathrm{pp}$.

Lanyon, J. M., Limpus, C. J., and Marsh, H. (1989). Dugongs and turtles: grazers in the seagrass system. In 'Biology of Seagrasses: A Treatise on the Biology of Seagrasses with Special Reference to the Australian Region'. (Eds A. W. D. Larkum, A. J. McComb and S. A. Shepherd.) pp. 61034. (Elsevier: Amsterdam.)

Lipkin, Y. (1975). Food of the Red Sea dugong (Mammalia : Sirenia) from Sinai. Israel Journal of Zoology 24, 81-98.

Marsh, H., Channells, P. W., Heinsohn, G. E., and Morrissey, J. (1982). Analysis of stomach contents of dugongs from Queensland. Australian Widlife Research 9, 55-67.

Spain, A. V., and Heinsohn, G. E. (1973). Cyclone associated feeding changes in the dugong (Mammalia: Sirenia). Mammalia 37, 678-80.

Wake, J. (1975). A study of the habitat requirements and feeding biology of the dugong, Dugong dugon (Müller). B.Sc. Honours Thesis, James Cook University of North Queensland, Townsville. $132 \mathrm{pp}$. 
